\title{
A MODEL OF COMMUNITY-BASED RURAL TOURISM PRODUCTS DEVELOPMENT
}

\author{
I Made Adikampana ${ }^{1}$, I Nyoman Sunarta ${ }^{2}$, Ni Luh Kerti Pujani ${ }^{3}$ \\ ${ }^{1}$ Email : adikampana@unud.ac.id \\ Program Studi Destinasi Pariwisata, FakultasPariwisata, Universitas Udayana \\ ${ }^{2}$ Email : nyoman_sunarta@unud.ac.id \\ Program Studi Destinasi Pariwisata, FakultasPariwisata, Universitas Udayana \\ ${ }^{3}$ Email : kerti_pujani@unud.ac.id \\ Program Studi Destinasi Pariwisata, FakultasPariwisata, Universitas Udayana
}

\begin{abstract}
The local community always took for granted the establishment of a tourist village as a rural tourism product. Likewise prevailed in Pinge Tourism Village, Tabanan Regency, Bali. In the context of developing rural tourism products in the Pinge Tourism Village, the participation of local communities is required to ensure the sustainability of tourism in rural areas. This paper aims to build a model for developing local community-based rural tourism products in Pinge Tourism Village. Community-based tourism (CBT) approaches are used to formulate models for rural tourism product development. The required data is collected through observation and interviews and then analyzed descriptively. The results of the analysis indicate local community-based rural tourism products are tourist pull factors in rural areas in the form of environmental characteristics and the practice of rural communities. The uniqueness of rural character and rural community routines are tourism capital posses by local communities. In addition to physical and socio-cultural uniqueness, rural tourism products are also determined by conformity with the target market. The existence of this rural tourism product model can increase local community participation in decision making and sharing of tourism benefits.
\end{abstract}

\begin{abstract}
Abstrak: Masyarakat lokal cenderung menerima begitu saja pengembangan desa wisata sebagai produk wisata pedesaan. Demikian juga berlaku di Desa Wisata Pinge, Kabupaten Tabanan, Bali. Dalam konteks pengembangan produk wisata perdesaan di Desa Wisata Pinge, partisipasi masyarakat lokal diperlukan untuk memastikan keberlanjutan pembangunan pariwisata. Tulisan ini bertujuan untuk membangun model pengembangan produk wisata perdesaan berbasis masyarakat lokal di Desa Wisata Pinge. Pendekatan pariwisata berbasis masyarakat digunakan untuk merumuskan model pengembangan produk wisata perdesaan. Data yang dibutuhkan dikumpulkan melalui observasi dan wawancara dan kemudian dianalisis secara deskriptif. Hasil analisis menunjukkan produk pariwisata perdesaan berbasis masyarakat lokal adalah faktor penarik kunjungan dalam bentuk karakteristik lingkungan perdesaan dan kehidupan keseharian masyarakat perdesaan. Keunikan karakter perdesaan dan rutinitas masyarakat perdesaan adalah sumber daya pariwisata yang dimiliki oleh masyarakat lokal. Selain keunikan fisik dan sosial-budaya, produk pariwisata perdesaan juga ditentukan oleh kesesuaian dengan pasar yang disasar. Keberadaan model produk pariwisata perdesaan ini dapat meningkatkan partisipasi masyarakat lokal dalam pengambilan keputusan dan pembagian manfaat pariwisata secara adil.
\end{abstract}

keywords : product, cbt, market, pinge tourism village. 


\section{INTRODUCTION}

The participation of local community in the development of tourism products in rural areas is the main requirement to ensure the sustainability of rural tourism development (Bramwell, 2010; Byrd et al., 2009; Zou et al., 2014). The local community can involve in the development of tourism products in form of decision-making and the sharing of benefits (Garrod et al., 2001; Timothy and Boyd, 2003). Engaging in decision making means that the community has the opportunity to voice their hopes, desires, and concerns about the development of tourism products, which in turn is an input in the tourism product planning process (Gunn and Var, 2002). Murphy (1985) also mentions the importance of involving the community in tourism planning. The involvement of the community in the tourism planning process is a determinant of the sustainability of tourism development. Whereas participation in the sharing of tourism benefits contains the intention that the community has the right to obtain economic benefits, quality of life, and environmental services from the development of tourism products in the vicinity.

Community-based tourism products can be developed on the basis of tourism resources that posses by local communities and suitable with targeted markets (Gunn and Var, 2002; Singh, et al., 2003; Reid, et al., 2009). The tourism resources in this context are the form of a pull factor, which is actually owned by the local community. While the suitability of the market means making selections on tourists who actually visiting the destination. This selection is significant for getting tourists who are in accordance with the attractions that are offered or well known as quality markets.

This study aims to formulate a local community based rural tourism product development model in Pinge Tourism Village. The model in question is a community-based tourism product development program. The local government in 2004 has established this tourism village. Until now it still has problems in providing quality rural tourism products. To achieve the objectives of the study, several research questions have been set up as the target of research, specifically: what rural tourism resources do local communities have? what are the actual and potential markets for rural tourism? and how are community-based rural tourism product development programs in Pinge Tourism Village?

\section{METHOD}

The community-based tourism (CBT) approach is utilized to answer several research questions. Reid, et al. (2009) stated that community-based rural tourism products were identified based on tourism resources or the uniqueness of local communities and the compatibility to the targeted markets.

Based on this approach, figured two research variables that are the variety of tourism resources and market characteristics in Pinge Tourism Village. Data related to research indicators were collected in primary and secondary to obtain qualitative and quantitative data. Data requirements gathered through a variety of techniques, hat is observation, tourist surveys, and interviews. The collected data will be grouped and interpreted according to the research target, then analyzed and synthesized descriptively to achieve the research objectives.

\section{RESULT AND DISCUSSION Tourism Resources}

Pinge Tourism Village has a variety of resources that can be developed as rural tourism products based on local communities. Ranging from physical environmental resources to a variety of social and cultural elements (Adikampana et al, 2017).

1. Environment resources

Administratively, Pinge Tourism Village is located in Marga District, Tabanan Regency, Bali Province. This tourism village has a unique form of territory that is linear extending along the road with an area of $240.75 \mathrm{Ha}$. Most of the land is used as agricultural land, while the remainder is for housing and communal facilities. The area of rice fields in Pinge Tourism Village is $105 \mathrm{Ha}$ or around $44 \%$ of the total village area. Moreover, local people also cultivate horticulture plants: vegetables and flowers. The results of these fields are mostly to meet the daily needs of the local community (subsistence). Apart from the results of rice fields, local communities also fulfill their needs from the results of the moors and yards. Space utilized for moors and yards is usually in backyard area or around the residence. The moors and 
yards in Pinge Tourism Village are mostly planted with a variety of fruits.

2. Socio-cultural resources

Social-cultural resources in tourism are social systems, cultural systems, and systems of work that are produced and implemented in the form of people's daily life (Feighery, 2008). Thus the sociocultural resources in the Pinge Tourism Village can be composed into rural tourism products in the form of temples and archaeological remains, village patterns, the spatial design of settlement, arts, and the banjar as smallest traditional organizations unit in Bali.

\section{Tourism Market}

The numbers of visitors to the Pinge Tourism Village in the period of 2011 to 2017 werefluctuated with positive trends. The average number of visits per year is 1.210 visitors. Visitors to the Pinge Tourism Village based on length of stay can be classified into two types that arean overnight visitor and oneday visitors.

Table 1. Number of Visitation to Pinge Tourism Village

\begin{tabular}{rrrrr}
\hline & & \multicolumn{3}{c}{ Visitor } \\
\cline { 3 - 5 } No. & Year & Overnight & $\begin{array}{c}\text { One- } \\
\text { day }\end{array}$ & Total \\
\hline 1 & 2011 & 219 & 847 & 1.066 \\
\hline 2 & 2012 & 229 & 912 & 1.141 \\
\hline 3 & 2013 & 186 & 673 & 859 \\
\hline 4 & 2014 & 242 & 910 & 1.152 \\
\hline 5 & 2015 & 354 & 1.280 & 1.634 \\
\hline 6 & 2016 & 806 & 1.016 & 1.822 \\
\hline 7 & 2017 & 435 & 363 & 798 \\
\hline & Total & 2.471 & 6.001 & 8.472 \\
\hline
\end{tabular}

Source :PokdarwisDesaPinge, 2018

Most tourists or visitors that staying in Pinge Tourism Village are from Europe, mainly from French and German. In addition, tourists also from the Asia Pacific such as Japan and China. The tourists stayed in several houses that were also used as homestays. Furthermore, in accordance with the age of tourists, it can be mentioned that the tourism market in Pinge Tourism Village is dominated by the age range of 25-55. Generally, this range is productive, independent, and has high and stable financial capabilities. Their choice of tourism products is to interact with local communities to know or even learn about local culture. Besides, the baseline for the development of local community-based tourism products in Pinge Tourism Village is that there are quite a number of elderly tourists or order retired who usually visit this destination with their partners.

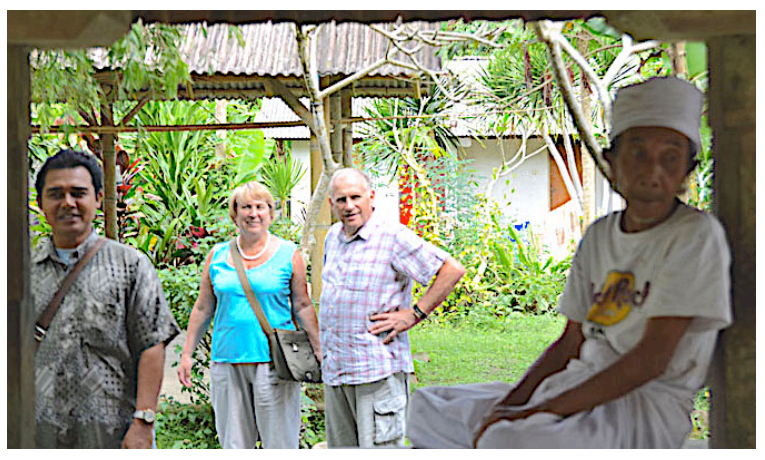

Figure 1. Host and Guest Interaction

\section{Community-Based Rural Tourism Product}

Accordance with the mapping of tourism resources, it can be stated that the Pinge Tourism Village has a uniqueness which is the basis for the development of tourism village products created by the local community. The uniqueness is the combination of the physical environment and also daily activities or referred to as the social, cultural and economic routines of the local community (Adikampana et al, 2017):

1. Villages that have many shrines and various religious rituals. This makes Pinge Tourism Village rich of religious activities. This uniqueness is called Spiritual Routines.

2. Rice fields, moors, and yards dominate Land use. The majority of the livelihoods of local community are farmers with subsistence culture. This condition raises the theme of Agricultural Routines.

3. Local food and beverages (FB) are processed from self-produced ingredients. The process of taking food ingredients, cooking, serving, and enjoying food is part of the daily life of the local community. The daily life of the local community is termed of FB Routines.

4. Banjar as a media to meet and gather local communities in order to share various information and performing art. These various Communal Routines are concentrated in the Bale Banjar. 
Based on actual demand for tourism in Pinge Village, it can be stated that the market target for products in Pinge Tourism Village is a tourist from France and Germany and other European countries as the main markets. In addition to the main market, there are several countries that can be targeted as potential markets, particularly tourists from Japan, China and the domestic market. The main and potential markets, especially Japan, are very relevant to rural tourism development. This is caused by tourists from these countries having a strong interest in some of the following indicators: experience local culture, experience natural environment, quiet and tranquil, experience local gastronomy, meet new people, experience the outback, stay in local village, adventure activities, visit a heritage area, and to learn about culture and nature. Moreover, market sources from China and the domestic can also be used as alternative targets for the rural tourism market, given the strategic value of these two market sources. Tourists from China are Bali's largest market in the past five years and are expected to continue to grow in the future. While the domestic market is currently pushed to move to rural areas for the purpose of learning, strengthening, and encourage a pride in Indonesian culture, because the center of Indonesian culture actually exists in rural areas.

Rural tourism products are the development of values contained in physical, social, and authentic cultural objects in rural areas to provide new experiences for tourists (Idziak et al., 2015). Tourists who visit rural areas are motivated to experience life directly or do daily activities in rural communities (George et al., 2009; Roberts and Hall, 2001). In the context of Pinge Tourism Village, the determination of rural tourism products in the tourist village is based on the values of the physical, social, and cultural environment that appear in the daily activities or routine of the local community. Some of the products of Pinge Tourism Village that can be offered to market or tourist targets as a model for developing local community based rural tourism product include:

1. Spiritual Engagement;

Tourists who choose this product will get experience and learning about ritual and spiritual processes, especially in Hindu religious ceremonies. Various experiences and learning are obtained starting from the stages of preparation ceremony, making ceremonial facilities, to conducting religious ceremonies.

2. Agricultural Activity

Tourists can take part in the whole process of agricultural cultivation, to gain experience and learning of agricultural based on the subaksystem which has been established as a world cultural heritage.

3. Culinary Experience

The experience and learning of processing food and beverage (FB) ingredients and enjoying fresh and healthy culinary was only found in Pinge Tourism Village. The types of food and beverage in Pinge Tourism Village are very typical because most of the raw materials are produced in the village itself. Tourists will be able to take food and beverage ingredients and then cooking together with the local community.

4. Educational Recreation

One of the purposes for tourism is to study the tourist attractions visited in the interim period. Pinge Tourism Village has a unique cultural heritage in the form of old village characters, traditions, and natural attributes that can be informed to tourists to enrich their experience and knowledge.

5. Rural-nightlife Attraction

The activities carried out are interacting with the local community after the community has worked all day in the fields, moors, and yards enjoying the art displayed and learning to do art by dancing or playing one type of traditional musical instrument located in balebanjar.

6. Retirement Village Intended for elderly tourists or retirees who want to stay longer in Pinge Tourism Village. This tourism product is also equipped with facilities and services including care can be provided as required.

\section{CONCLUSION}

Through the mapping of tourism resources, it can be determined the themes of the development community based rural tourism product. There are four themes that can be taken into consideration for the development of local communities based rural tourism products in Pinge Tourism Village: Spiritual Routines, Agricultural Routines, FB Routines, and Communal Routines. The four 
themes become the basis for determining rural tourism products or special interest tourism activities in traditional Balinese villages at Pinge Tourism Village. The construction of rural tourism products is also adjusted to the targeted market. Based on an actual visitation to Pinge Tourism Village, it can be stated that the market target for the product is a tourist from France and Germany and other European countries as the main markets. In addition to the main market, there are several countries that can be targeted to become potential markets, which are tourists from Japan, China, and the Indonesian market.

The discussion of the theme of tourism products and the tourism market can determine the formulation of a rural community-based tourism product development program. Some of local community-based rural tourism products that can be built in Pinge Tourism Village include Spiritual Engagement, Agricultural Activity, Culinary Experience, Educational Recreation, Rural-nightlife Attraction, and Retirement Village. These tourism product initiated will be able to increase the participation of local people in rural tourism development and be able to provide experience and learning about heritage inheritance and noble traditions for tourists. In addition to the expected increase in the type of community participation, the existence of tourism products that are in accordance with local community resources can also arouse the awareness and pride of the local community towards their resources, so as to strengthen awareness and efforts to preserve tourism resources, to ensure the development of sustainable tourism in Pinge Tourism Village. 


\section{Kepustakaan}

Adikampana, I M., Sunarta, I N., and Negara, I M. Kusuma. 2017. Arahan Produk Pariwisata Berbasis Masyarakat Lokal Di Wilayah Perdesaan. Jurnal IPTA, 5: 92101.

Bramwell, B., 2010, Participative Planning and Governance for Sustainable Tourism. Tourism Recreation Research, 35: 239249.

Byrd, Erick T., Bosley, Holly E., and Dronberger, Meghan G., 2009, Comparisons of stakeholder perceptions of tourism impacts in rural eastern North Carolina, Tourism Management, 30: 693703.

Feighery, William G. 2008. "Heritage Tourism in Xi'an: Constructing the Past in Contested Space". Dalam Janet Cochrane (ed). Asian Tourism: Growth and Change. Elsevier, UK.

George, E. Wanda, Mair, H., and Reid, Donald G. 2009. Rural Tourism Development: Localism and Cultural Change. Channel View Publications, UK.

Gunn, C. A. and Var, T., 2002, Tourism Planning: Basics, Concepts, Cases, Routledge, London.

Garrod, B., Wilson, J.C., and Bruce, D.B., 2001, Planning for Marine Ecotourism in the EU Atlantic Area: Good Practice Guidelines, Project Report, University of the West of England, Bristol.

Idziak, W., Majewski, J., and Zmyślony, P., 2015, Community participation in sustainable rural tourism experience creation: a long-term appraisal and lessons from a thematic villages project in Poland, Journal of Sustainable Tourism, 23:1341-1362.

Murphy, Peter E., 1985, Tourism A Community Approach, Methuen, New York.

Reid, D. G., George, E. W., and Mair, H., 2009, Rural Tourism Development;
Localism and Cultural Change, Channel View Publications, UK.

Roberts, L. and Hall, D., 2004, Consuming the countryside: Marketing for rural tourism, Journal of Vacating Marketing, 10: 253263.

Singh, S., Timothy, D. J., and Dowling, R. K., 2003, Tourism in Destination Communities, CABI, UK.

Timothy, Dallen J. and Boyd, Stephen W., 2003, Heritage Tourism, Pearson Education, England.

Zou, T., Huang, S., and Ding, P., 2014, Toward A Community-driven Development Model of Rural Tourism: The Chinese Experience, International Journal of Tourism Research, 16: 261271. 